\title{
Ecological Study of Indigenous Tree Population and Potentials in Urban Green Space: A Case Study of Benin Teaching Hospitals, Benin- City, Edo State, Nigeria
}

\author{
Erhabor $\mathrm{TA}^{1}$, Dahunsi $\mathrm{OM}^{2}$, Baba $\mathrm{GO}^{2}$, Olaifa $\mathrm{RK}^{2 *}$, Sodimu $\mathrm{A}^{1}$ \\ ${ }^{T}$ Federal College of Forestry, Jos, Plateau State, Forestry Research Institute of Nigeria \\ ${ }^{2}$ Savanna Forestry Research Station, Forestry Research Institute of Nigeria, PMB 1039, Samaru, Zaria, Kaduna State \\ *Corresponding Author \\ Olaifa RK
}

\section{Article History}

Received: 14.10 .2020

Accepted: 02.11.2020

Published: 03.12.2020

\begin{abstract}
Planning and establishment of urban forests/trees for bio-physical benefits is not new in Nigeria; however, development and management of urban forests/trees for social and cultural values is relatively recent. This study is a diagnostic assessment of all trees/shrubs within University of Benin Teaching Hospital, Benin-City, Nigeria, including the newly introduced indigenous tree species. Ecological analysis was used to describe the relic tree population while ANOVA was used to compare growth in height and mortality of Mansonia altissima, Tieghemela heckelii, Terminalia superba, Khaya grandifoliola, Nauclea diderichii and Piptadeniastrum africanum. There were 224 trees/shrubs consisting of indigenous (15\%) and exotic (85\%) - distributed among 27 species, 26 genera and 19 families. Shannon Weiner index (2.65) revealed low species diversity while Terminalia mantaly ranked highest on Important Value Index (IVI) scale. Tree/shrub height ranged $2 \mathrm{~m}$ to $6 \mathrm{~m}$ while most stems $(68 \%)$ recorded $\leq 20 \mathrm{~cm}$ dbh. Ornamental plants $(41 \%)$ tending toward mature growth stage dominated the landscape. The study revealed that Khaya grandifoliola had a significantly better $(\mathrm{P} \geq 0.05)$ annual growth rate $(1.74 \mathrm{~m})$ but also recorded highest $(62.5 \%)$ mortality rate in the urban environment. Relative high growth rates of $K$. grandifoliola and Nauclea diderichii present a possible alternative to some exotic tree species in urban green spaces.
\end{abstract}

Keywords: Urban forests, Species diversity, Indigenous trees, Exotic trees, Population.

\section{INTRODUCTION}

In Nigeria, just like in most developing countries, increase population, industrialization and urbanization have led to the concentration of economic and social activities in urban and peri-urban areas. This trend has imposed negative consequences on the environment, food and health security, mainly because of the removal/depletion of the vegetation cover provided by indigenous trees /shrubs, many of which are greatly threatened or endangered. It is therefore important to manage the relic trees in urban areas and establish/manage wood lots in open or degraded areas. Urban forestry is therefore one of the promising strategies to address the multifaceted problems associated with urbanization [1]. But this to a large extent will depend on the structure of the urban forest and the management practices put in place by the stakeholders.

Climate change and negative externalities are the greatest problems faced by the world today. Global warming has caused much environmental stress especially heat waves and flooding which are affecting inhabitants in towns and cities as well as public facilities like hospitals and as such the cost of managing medical and other public facilities is rising astronomically. Urban forestry offers magnitude of benefits to the inhabitants of towns and cities and contributes significantly to human health and environmental quality. In the quest to building healthy and sustainable cities, greening with trees provide invaluable recipe for building or developing parks in boulevards and open spaces. They help improve human health and livelihood systems, conserve biodiversity, protect properties against extreme climate events, erosion, wind, dust, haze, etc

Copyright (C) 2020 The Author(s): This is an open-access article distributed under the terms of the Creative Commons Attribution 4.0 International License (CC BY-NC 4.0) which permits unrestricted use, distribution, and reproduction in any medium for noncommercial use provided the original author and source are credited. 
Planning and establishment of urban forests/trees for bio-physical benefits is not new in Nigeria; however, the development and management of urban forest/trees for their social, cultural and amenity values is relatively recent. Forest management in Nigeria is the prerogative of state government while urban/peri-urban forests are controlled by local government, municipal authorities and/or agencies. An assessment of the total tree species and canopy cover in urban centres is a critical element towards building and management of the well-being of cities and towns. Unlike the traditional (rural) forests, urban forests are amenable to planning, protection and control. Local communities, schools, community development associations, business entities, industries, Local, State, Federal Government and individuals have a stake in urban forest management and conservation.

In Nigeria, urban forests are often dominated by fast growing exotic species like Polyalthia longifolia, Delonix regia, Gmelina arborea, Terminalia catappa and Tectona grandis as well as fruit trees, notably Mangifera indica, Psidium guajava, Anarcadium occidentale, Anona muricata etc. However, there are evidences [2, 3] that town and city consumers in Nigeria have preferences for products of indigenous trees. These indigenous trees are increasingly disappearing from urban areas while most of them are yet to be adequately characterized. The use of indigenous forest trees in urban forest planning and design is important because it enhances conservation of biodiversity (both tree species and associated biotic communities), and creates opportunities for improved livelihood systems. Introduction of indigenous forest species especially those on the IUCN red list (such as Mansonia altissima, Pericopsis elata, Nauclea diderichii, Khaya grandifoliola etc.) in the greening of urban landscape will in addition to serving as orchards or wood/seed lots help in conserving the species and ameliorating the environment.

University of Benin Teaching Hospital (UBTH), Benin City, is one of Nigeria's first generation national health institutions, situated on relatively flat terrain with modest greenery flanking roads, offices and residences. In 2016, greening projects using indigenous trees species to substitute old, dead and/or dying trees was embarked on and this paper is the outcome of a diagnostic survey of all trees/shrubs within UBTH premise and an exploration of opportunity of replacing the malformed, dead and dying exotic species with fast growing indigenous economic species in University of Benin Teaching Hospital, Benin City, Nigeria.

\section{Materials AND Method Study Area}

The study was carried out at the University of Benin Teaching Hospital (UBTH), Benin City, Nigeria (Longitudes $6^{\circ} 11^{\prime}$ to $6^{\circ} 29^{\prime} \mathrm{N}$ and Longitude $5^{\circ} 33^{\prime}$ to $5^{\circ} 47^{\prime} \mathrm{E}$ ). The hospital was established in the early 1970 s and located on a 60ha land near University of Benin, Ugbowo Main Campus, Benin City, along Benin-Lagos express way and about $8 \mathrm{~km}$ from the city center. UBTH attends to an average of 3,327 out patients every month with over $30 \%$ of the patients coming in as out-patients from Edo State and other neighboring states of South-Southern Nigeria [4]. The hospital currently has a workforce of over 4000 personnel consisting of clinical and non-clinical staff.

\section{Sampling Technique and Data Collection}

$100 \%$ population count or tree demography was carried out in the hospital. Trees were identification following Keay [5] and categorized on the bases of use value: fruit trees, ornamental/amenity trees or forest (timber) trees. Species were also classified on the bases of the following variables measured:

\section{Total tree population 2. Tree height 3. Girth at breast height $(\mathrm{GBH})$}

The heights and diameters at breast height of the trees were estimated using a Range Finder and a girthing tape respectively to group trees into diameter and height classes

\section{Performance of saplings of introduced indigenous tree species}

The performance of seven indigenous tree species, namely; Nauclea diderichii, Terminalia superba, Khaya grandifoliola, Piptadeniastrum africanum, Mansonia altissma and Tieghemela heckenii was evaluated. The population of the species at the commencement of this study is presented table 1.

Table-1: Population of Saplings Indigenous Species Planted in UBTH

\begin{tabular}{|l|l|l|l|}
\hline S/N & \multicolumn{1}{|c|}{ Species } & Population & Percentage (\%) \\
\hline 1 & Khaya grandifoliola & 7 & 1.4 \\
\hline 2 & Mansonia altissima & 4 & 0.8 \\
\hline 3 & Nauclea diderichii & 363 & 72.3 \\
\hline 4 & Piptadeniastrum africanum & 16 & 3.2 \\
\hline 5 & Terminalia superba & 100 & 19.9 \\
\hline 6 & Teighemela heckelii & 12 & 2.4 \\
\hline
\end{tabular}


For species of population less or equal to twenty (Table 1), one hundred percent sampling intensity was applied while twenty percent sampling intensity was applied to species with population greater than twenty. Height of saplings was measured and recorded at two weeks' intervals for a period of 24 weeks while final species indices (height, crown diameter and total number of saplings) were obtained after 18 months.

\section{Statistical Tool and Data Analysis}

Ecological analysis such as species relative density, species relative dominance, important value index etc were estimated and used to describe the tree population and diversity of the study area while annual growth rates and mortality rate were estimated to describe the growth performances of planted indigenous tree species and their mortality. Means were compared using DMRT and t-statistics was used to compare RGR at 6 months and 24 months.

\section{Species relative density $(\mathrm{RD} \%)$}

$\mathrm{RD}=\left(\mathrm{n}_{\mathrm{i}} / \mathrm{N}\right) \times 100$

Where $\mathrm{n}_{\mathrm{i}}=$ number of individual of species and $\mathrm{N}=$ total number of all trees in the study area.

Species Relative Dominance: Species relative dominance $\left(\mathrm{RD}_{\mathrm{o}}\right)$, used in assessing relative space occupancy, was estimated using

$\mathrm{RD}_{\mathrm{o}}=\left(\sum \mathrm{Ba}_{\mathrm{i}} \mathrm{X} 100\right) / \sum \mathrm{Ba}_{\mathrm{n}}$

Where $\mathrm{Ba}_{\mathrm{i}}=$ basal area of all trees belonging to particular species $\mathrm{i}$; $\mathrm{B}_{\mathrm{n}}=$ basal area of all trees in the study area

Important Value Index: The important value index (IVI) of each species was computed with the relationship

$$
\mathrm{IVI}=\frac{R D+R D O}{2}
$$

Shannon Weiner's Index of Diversity: Species diversity index was computed using Shannon Weiner diversity index $[16,17]$

$$
\mathrm{H}=\sum \mathrm{p} \ln \mathrm{P}_{\mathrm{i}}
$$

Where $\mathrm{P}$ is the proportion of important values of the ith species and $\mathrm{P}=\frac{n i}{N}$

$\mathrm{n}_{\mathrm{i}}=$ total number of individuals of species $\mathrm{I}$ and $\mathrm{N}=$ total number of individuals of all species

\section{Shannon's Maximum Diversity Index}

Shaannon's maximum diversity index was calculated using

$$
\mathrm{H}_{\max }=\mathrm{In}(\mathrm{S})
$$

Where $\mathrm{H}_{\max }=$ shaannon's maximum index and $\mathrm{S}=$ total number of species in the study area

\section{Mortality Rate}

$$
\mathrm{M}=100\left(\operatorname{Ln~N}_{\mathrm{o}}-\operatorname{Ln} \mathrm{N}_{\mathrm{t}}\right) / \mathrm{t}
$$

$\mathrm{N}_{\mathrm{t}}=$ number of individuals at time $\mathrm{t}, \mathrm{N}_{\mathrm{o}}=$ initial number of individual at $\mathrm{t}=0$ and $\mathrm{t}=$ number of years.

$\underline{\text { Relative Growth Rate (RGR) }}$

$$
\mathrm{RGR}=\left(\mathrm{Ln} \mathrm{H}_{\mathrm{t}}-\mathrm{Ln} \mathrm{H}_{\mathrm{o}}\right) / \mathrm{t}
$$

Where $\mathrm{H}_{\mathrm{t}}=$ Height at time $\mathrm{t}$ years, $\mathrm{H}_{\mathrm{o}}=$ initial height at $\mathrm{t}=0$ and $\mathrm{t}=$ number of years.

Note that for $\mathrm{t}<1$,

$t=t_{d} / 365$ where $t_{d}=$ number of days.

\section{RESULT}

\section{Tree Diversity and Abundance}

There were 224 trees ( $\geq 10 \mathrm{~cm}$ gbh) consisting of indigenous (9) and exotic (18) disproportionately distributed among 27 species, 26 genera and 19 families. The species population distribution was in the order: $14.7 \%$ indigenous and $85.3 \%$ exotic (Table 2). Ornamental trees were most abundant $(40.63 \%)$ while forest trees, fruit trees and others accounted for $6.7 \%, 37.95 \%$ and $14.72 \%$ respectively. Terminalia mentaly had the most abundant stems (54). 
Erhabor TA et al; South Asian Res J Agri Fish; Vol-2, Iss-6 (Nov-Dec, 2020): 171-178

Table-2: Tree Species at University of Benin Teaching Hospital

\begin{tabular}{|c|c|c|c|c|}
\hline FAMILY & SPECIES & ORIGIN & USE & FREQUENCY \\
\hline \multirow[t]{3}{*}{ Anacardiaceae } & Anacardium occidentale & Exotic & Fruit & 1 \\
\hline & Mangifera indica & Exotic & Fruit & 18 \\
\hline & Spondias mombin & Exotic & Fruit/medicinal & 6 \\
\hline \multirow[t]{2}{*}{ Annonaceae } & Annona muricata & Exotic & Fruit & 2 \\
\hline & Polyalthia longifolia & Exotic & Ornamental & 28 \\
\hline Apocynaceae & Alstonia boonei & Indigenous & Timber/medicinal & 6 \\
\hline Bignoniaceae & Newbouldia laevis & Indigenous & Medicinal & 14 \\
\hline Burseraceae & Decryodes edulis & Indigenous & Fruit & 2 \\
\hline Casuarinaceae & Casuarina equisetifolia & Exotic & Ornamental/timber & 2 \\
\hline \multirow[t]{2}{*}{ Combretaceae } & Terminalia catappa & Exotic & Ornamental/fruit & 17 \\
\hline & Terminalia mentaly & Exotic & Ornamental & 54 \\
\hline \multirow[t]{2}{*}{ Euphorbaceae } & Hura crepitans & Exotic & Ornamental & 1 \\
\hline & Ricinodendron heudelotii & Indigenous & Timber & 2 \\
\hline \multirow[t]{2}{*}{ Fabaceae } & Albizia lebbeck & Exotic & Timber & 3 \\
\hline & Delonix regia & Exotic & Ornamental & 4 \\
\hline Irvingiaceae & Irvingia spp & Indigenous & Fruit & 3 \\
\hline Lauraceae & Persea Americana & Exotic & Fruit & 10 \\
\hline \multirow[t]{2}{*}{ Malvaceae } & Cola Spp & Indigenous & Fruit & 1 \\
\hline & Theobroma cacao & Exotic & Fruit & 1 \\
\hline \multirow[t]{2}{*}{ Meliaceae } & Azadirachta indica & Exotic & Medicinal & 5 \\
\hline & Guarea cedrata & Indigenous & Timber & 1 \\
\hline Moraceae & Ficus capensis & Indigenous & Medicinal & 3 \\
\hline Moringaceae & Moringa oleifera & Exotic & Vegetable/medicinal & 3 \\
\hline Myrtaceae & Psidium guajava & Exotic & Fruit & 19 \\
\hline Pinaceae & Pinus spp & Exotic & Ornamental & 4 \\
\hline Rutaceae & Citrus spp & Exotic & Fruit & 13 \\
\hline Sterculaceae & Hlidergardia barteri & Indigenous & Timber & 1 \\
\hline
\end{tabular}

\section{Tree diameter and Height Classes}

The greatest number of stems $(35.27 \%)$ was recorded in dbh class $1-10 \mathrm{~cm}$ while only $6.7 \%$ was recorded in dbh class $>100 \mathrm{~cm}$ (Figure 1.). The distribution, which is skewed to the right, shows that over two-third of the trees in the hospital had $\mathrm{dbh} \leq 20 \mathrm{~cm}$. Indigenous species had larger dbh $(35.05 \mathrm{~cm})$ compared to exotic species $(29.33 \mathrm{~cm})$ with Hlidergardia barteri and Alstonia boonei ranking highest $(179 \mathrm{~cm})$ (Figure 2).

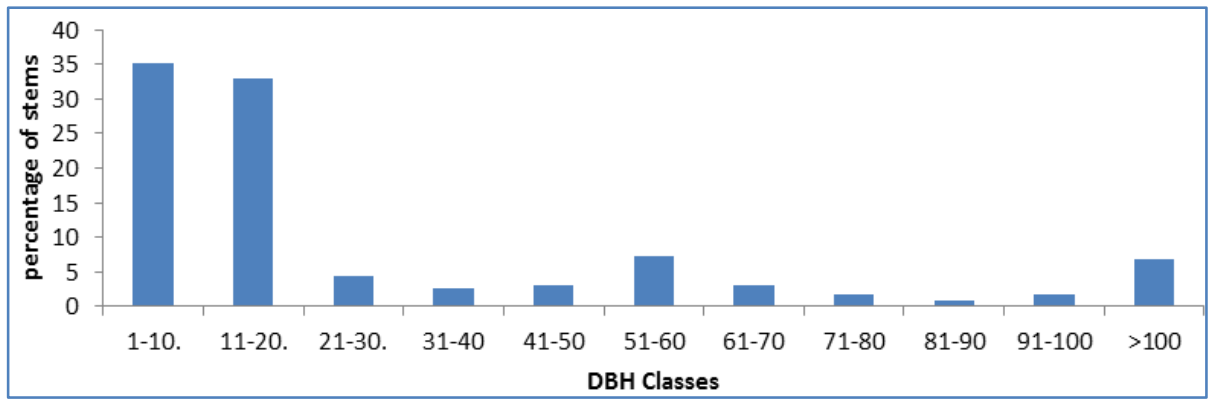

Fig-1: Distribution of Tree Population based on DBH

The height of most trees $(56 \%)$ ranged between 2.0 and $5.9 \mathrm{~m}$ (Figure 3.). Twenty seven percent were less than $2 \mathrm{~m}$ in height and only a few $(17 \%)$ were over $6 \mathrm{~m}$ in height. Mangifera indica was the tallest tree $(21.6 \mathrm{~m})$ in the study area but on the average, indigenous trees were taller $(6.61 \mathrm{~m})$ than exotic tree species $(5.84 \mathrm{~m})$, although the latter recorded more population of species (Figure 4). 


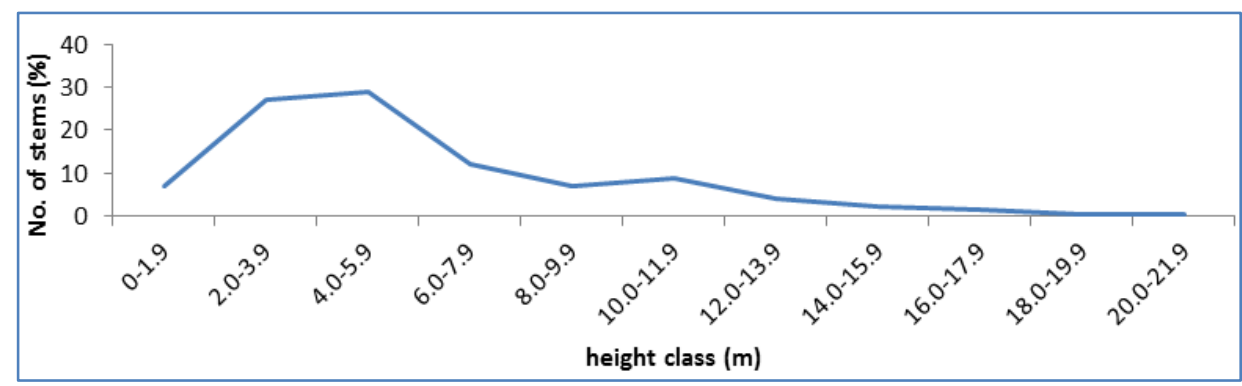

Fig-3: Height Class Distribution of Trees

\section{Species Importance Value}

Terminalia mentaly was the most important species (12.51) in the study area (Figure 5). Some other species with high important value indices (IVI) include Hlidergardia barteri (8.42), Mangifera indica (7.87), Terminalia catappa (7.12), Polyalthia longifolia (6.79) and Casuarina equisetifolia (5.32).

Tree diversity, using Shannon Weiner and Brillouin indices were 2.66 and 2.47 respectively while Shannon's maximum diversity index was 3.30 .

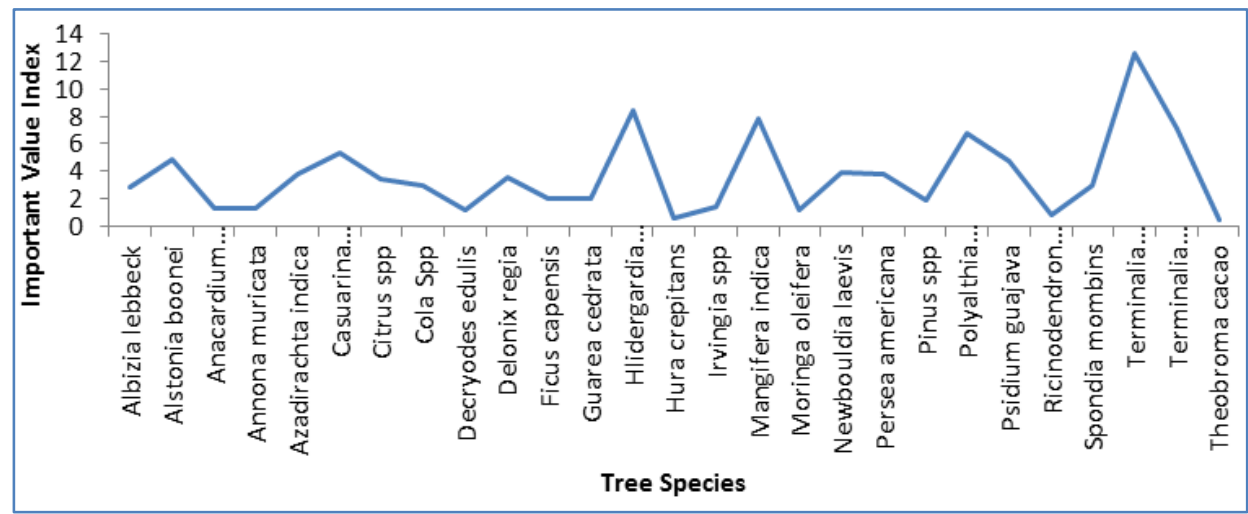

Fig-5: Important Value Indices of the Various Species

\section{Performance of saplings of introduced indigenous forest tree species \\ Height Increment of Saplings}

There was no significant difference $(\mathrm{p} \leq 0.05)$ in height increments of $N$. diderichii, $T$. superba, M. altissima and $P$. africanum measured at 2 weeks' interval for 6 MAP (Months after planting out). The height growth of these species were significantly better than that of $T$ heckelii $(0.9 \mathrm{~cm})$ but less than that of $K$. grandifoliola $(5.15 \mathrm{~cm})$ which was significantly best $(\mathrm{p} \leq 0.05)$ in height growth.

\section{Relative Growth Rate}

Khaya grandifoliola had a relative growth rate (RGR) of $1.73 \mathrm{~m}$ at $6 \mathrm{MAP}$ followed by Nauclea diderichii $(1.34 \mathrm{~m})$ while the least was Tieghemella heckelii $(0.58 \mathrm{~m})$. The relative growth rate of the species (Figure 7) shows that Khaya grandifoliola $(1.74 \mathrm{~m})$ was significantly better $(\mathrm{P} \geq 0.05)$ while Tieghemella heckelii $(0.57 \mathrm{~m})$ was significantly least. There was no significant difference in the growth rates of Nauclea diderichii $(1.34 \mathrm{~m})$, Terminalia superba $(1.04 \mathrm{~m})$ and Piptadeniastrum africanum $(0.98 \mathrm{~m})$. There were also no significant differences in the growth rates of Piptadeniastrum africanum, Terminalia superba and Mansonia altissima (0.75) as well as between Mansonia altissima and Tieghemela heckelii.

But after 24 months, the result showed that Nauclea diderichii $(0.91 \mathrm{~m})$ had the best growth (Plate 2 and 3 ), closely followed by Khaya grandifoliola $(0.9 \mathrm{~m})$ while Tieghemella heckelii $(0.18)$ was still the least in RGR (Figure 7). Analysis of the two sets of RGR (at 6 months and 24 months) resulted in t-statistics values $(\mathrm{t}=1.99$ and $\mathrm{P}=0.074)$. 


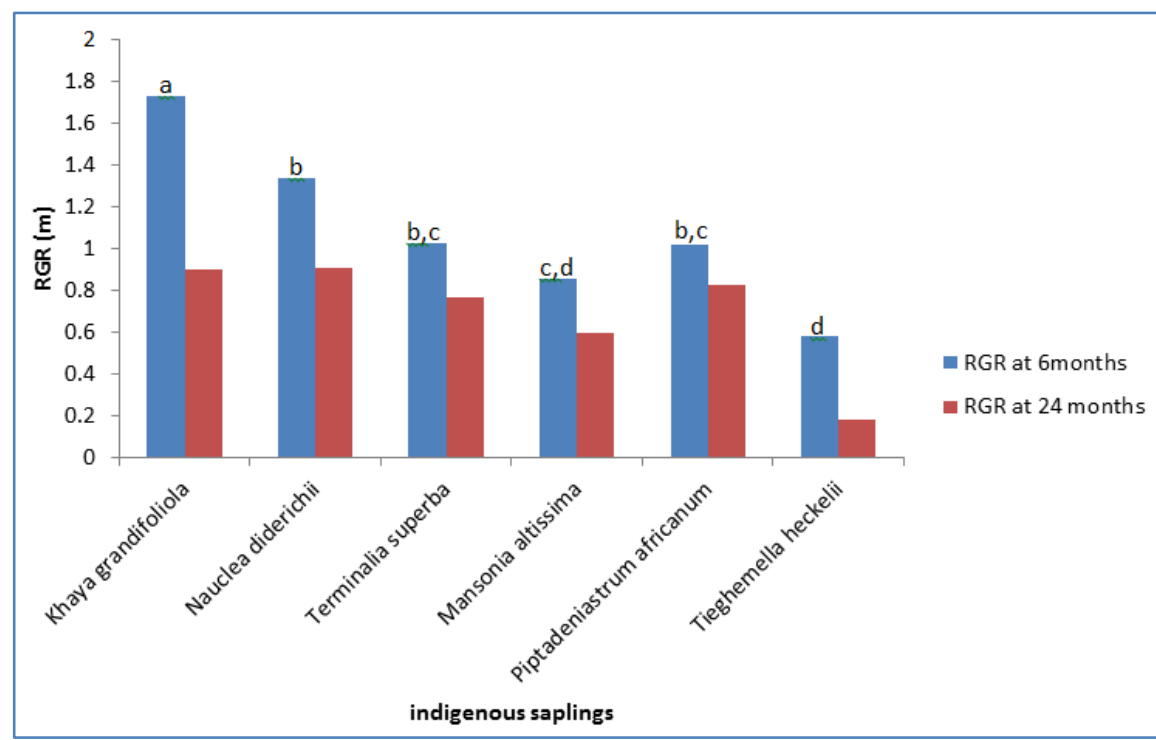

Fig-7: Relative Growth Rate (RGR) of the Indigenous SpecieS

\section{Mortality Rate}

After 6 months, K. grandifoliola and T. heckelii had very high mortality rates $(62.5 \%$ and $54.5 \%$ respectively) while $M$. altissima and $P$. african had $0 \%$ mortality (Figure. 8). After 24 months, K. grandifoliola (62.5\%) and T. heckelii $(89.59 \%)$ still had the highest mortality rates while M. altissima $(14.38 \%)$ remained least. It was observed that the mortality of $P$. africanum which was $0 \%$ at 6 months increase to $49.04 \%$. This was because some of the planted tree species were cut off to make room for infrastructural development at the hospital. It was observed that $N$. diderichii experience high level of disturbance but because of its ability to coppice, mortality was relatively low (14.29\% at 6 months and $29.73 \%$ at 24 months). T. superba had a mortality rate of $10 \%$ and $25.54 \%$ at 6 months and 24 months respectively.

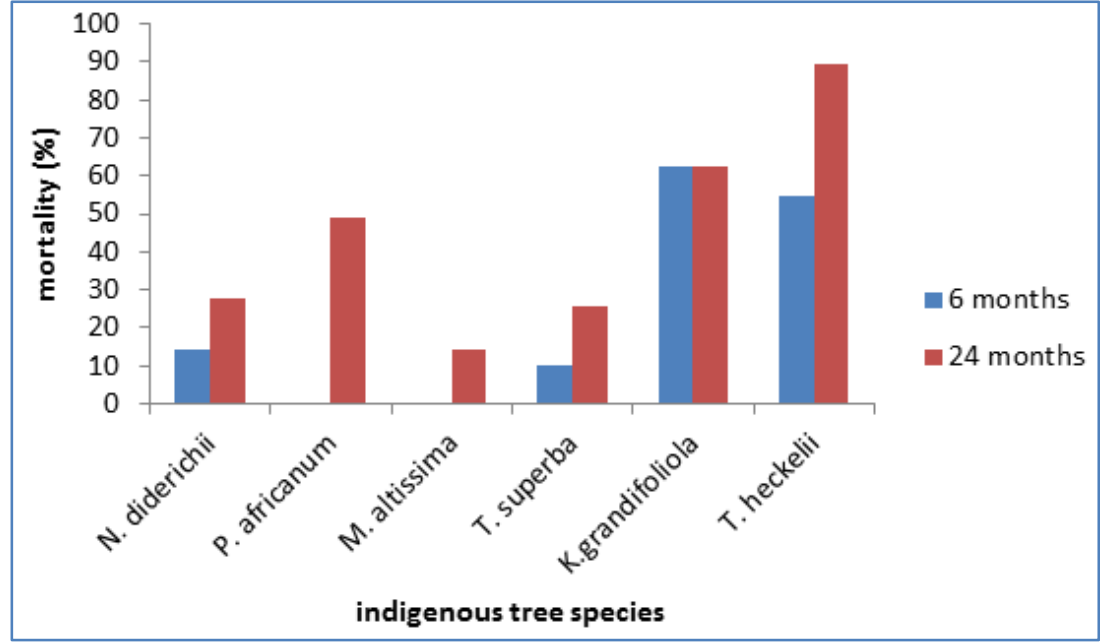

Fig-8: Mortality Rate of the Indigenous Tree Species

\section{Crown Diameter}

Record of crown diameter 24 MAP shows that P. africanum $(5.34 \mathrm{~m})$ had the greatest spread. This was closely followed by $N$. diderichii $(4.78 \mathrm{~m})$, T. superba $(2.94 \mathrm{~m})$ and $M$. altissima $(2.35 \mathrm{~m})$. Tieghemela. heckelii recorded the least crown diameter $(0.28 \mathrm{~m})$ while $K$. grandifoliola was $1.76 \mathrm{~m}$ (Figure 9$)$. 


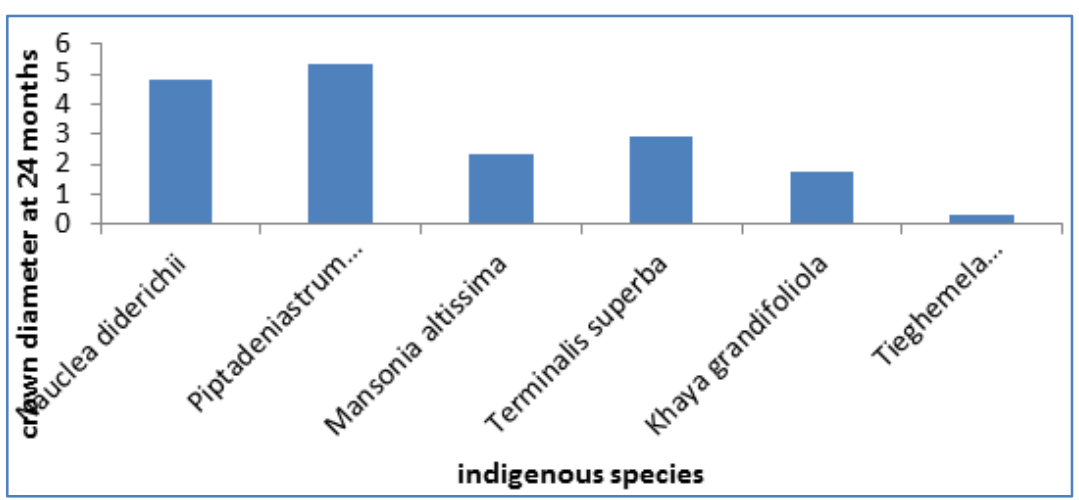

Fig-9: Crown diameter of sapling at 24 months after planting out

\section{DISCUSSION}

\section{Assessment of Tree Population and Diversity}

Assessment and characterization of tree species composition and diversity in urban, peri-urban and sub-urban environments is a vital source of information to management and is critical in the development of a sustainable urban forest. Several authors: Angermeier [6] and Aranson et al., [6], have reported the prevalence of exotic over indigenous species in urban forests and this is same in the hospital environment. The prevalence of ornamentals supports Gobster [7] who reported that "aesthetics is a primary dimension of people-landscape interaction".

Indigenous tree species such as Newbouldia laevis, Azadirachta indica, Spondia mombins and Moringa oleifera encountered in the study area were introduced into the hospital for live fencing around living quarters. This is an indication that indigenous species did not find relevance and were not intentionally introduced into the urban architecture until recently. Prevalence of small trees (bdh $\leq 20 \mathrm{~cm}$ and height $\leq 6 \mathrm{~m}$ ) in the hospital environment is an indication of a positive trend in urban greening and should be encouraged in order to sustain the trend.

Although tree diversity was low in the study area, Shannon Weiner index (2.65) falls within the ideal range (1.5 and 3.5) reported by Bibi and Ali [8]. Other measures of Shannon Wiener diversity index in urban environments in Nigeria include, Agbelade et al. [4] who recorded 3.35 and 2.48 for urban and peri-urban areas of Ibadan metropolis and Agbelade et al. [4] who recorded 3.56 and 2.24 for urban and peri-urban areas of the Federal Capital Territory respectively. These values when compared with that obtained in this study further shows that there is a good level of tree diversity especially when the size of the study area is put into consideration.

\section{Performance of Saplings of Introduced Forest Tree Species}

Fast growth rate of $K$. grandifoliola at early stage has been reported by Onefeli and Adesoye, [9], that the species grew significantly better in height than even Gmelina arborea and Tectona grandis (exotic species) in their sapling stages recording a height increment of $0.98 \mathrm{~m}$ per annum. It has been reported that in Nigeria saplings of $K$. grandifoliola can reach an average height of $1.05 \mathrm{~m}$ per annum and an average height of $1.35 \mathrm{~m}$ per annum in Cote d'Ivoir [10]. Nauclea diderichii also had a relatively good annual growth rate (1.34) and is far larger than $0.62 \mathrm{~m}$ per annum reported by Addo-danso [11]. Relative growth rates measured at 6 months and 24 months showed that growth rates measured at 24 months was generally less for all the species but not significantly different at $5 \%$ level of significance (P $=0.075, \mathrm{t}=1.99)$.

$K$. grandifoliola recorded the highest growth in height but it also had a high rate of mortality (62.5\%) only surpassed by $T$. heckelii $(89.6 \%)$. Other species were more resilient to disturbances while M. altissima and $P$ africanum had no mortality. There are reports that the inability to adapt to urban environmental conditions and disturbance [12] and inability to grow fast [9] are reasons for dominance of exotic species in urban environments. Identification of specific challenges such as high mortality of $K$. grandifoliola could be a positive step to addressing such challenges and enhance the use of the species in urban greening.

Trees in urban environment face several threats to their survival and growth that are different from those by trees in forests and nurseries [13] and inability of some species such as Tieghemela heckelii to adapt to urban environment could result in stunted growth or reduced life span [14], hence, care must be taken to reduce mortality of Khaya grandifoliola and other species in urban greeneries especially because of its fast growth.

A canopy spread of $5.34 \mathrm{~m}$ and $4.78 \mathrm{~m}$ by $P$. africanum and $N$. diderichii are strong indications that they could be good shade providing trees in urban greening. Canopy of trees is not only important in shade provision but in provision 
of many ecosystem services through the leaves in water quality maintenance, absorption of volatile organic compounds and air pollutants, oxygen supply and carbon sequestration [15]. This makes it a very important criterion in selection of species for urban greening. According to Calaza et al. [15], choosing tree species that will be large (both height and canopy spread) at maturity will maximize provision of ecosystem services.

\section{CONCLUSION}

As most prominent cities of the world have started intensifying actions to solve most challenges of urbanization through urban forest strategies, it is therefore essential to sensitize urban and city dwellers in Nigeria on the importance of urban trees/forest to their livelihood, health security and the environment. Information on the present state of urban/sub-urban forests and city people's perception as well as the need for intensified urban forest development is key to managements'/governments' decision making and action plans.

Although, UBTH is dominated by exotic tree species, the introduction of the indigenous tree species could change the tree population dynamics in the future. Khaya grandifoliola and Nauclea diderichii exhibited good growth and could be used in urban forest designs. The perceived importance of indigenous species in Nigeria are usually economic (timber, fuel wood medicinal and dietary). Introduction of these species in urban greening will help in the establishment of the ecosystem services provided by these species among urban dwellers. Beyond this, species with even less biophysical potentials may still find places in urban ecosystems for their conservation/preservation as well as research and social/cultural purposes

\section{REFERENCES}

1. Fuwape, J. A., \& Onyekwelu, J. C. (2011). Urban forest development in West Africa: Benefits and challenges. Journal of Biodiversity and Ecological Sciences, 1(1): 78-94.

2. Akindele, S. O., \& Fuwape, J. A. (1998). Wood-based industrial sector review. A consultancy report prepared as part of the National Forest Resources Study, Nigeria, 74.

3. Onyekwelu, J. C. (2001). Growth characteristics and management Scenarios for Plantation-grown Gmelina arborea and Nauclea diderrichii in South-western Nigeria. Hieronymus Verlag, Münich, Germany, 196

4. Agbelade, A. D., Onyekwelu, J. C., \& Oyun, M. B. (2016). Tree species diversity and their benefits in urban and peri-urban areas of Abuja and Minna, Nigeria. Applied Tropical Agriculture, 21(3), 27-36.

5. Keay, R.W.J., (1989). Trees of Nigeria. Oxford University Press, Oxford, 476 pp.

6. Angermeier, P. L. (1994). Does biodiversity include artificial diversity. Conservation Biology 8:600-602

7. Gobster, P.H. (1996). Forest aesthetics, biodiversity, and the perceived appropriateness of ecosystem management practices. In Proceedings: Workshop on Defining Social Acceptability of Forests and Forestry Practices. General Technical Report. PNW-369, eds Brunson M. W., Kruger

8. Bibi, F., \& Ali, Z. (2013). Measurement of diversity indices of avian communities at Taunsa Barrage Wildlife Sanctuary, Pakistan. The Journal of Animal \& Plant Sciences, 23(2), 469-474.

9. Onefeli, A., \& Adesoye, P. (2014). Early growth assessment of selected exotic and indigenous tree species in Nigeria. South-east European forestry, 5(1), 45-51.

10. Opoku, S. M. (2012). Growth and productivity of Khaya Grandifoliola in the Dry Semi-deciduous forest of Ghana: A Comparison in pure stands and in mixed stands (Ph.D. Thesis). Kwame Nkrumah University of Science and Technology. Ghana.

11. Addo-Danso, S.D., Bosu P.P., Nkrumah E.E., Pelz D.R., Coke S.A., \& Adu-Bredu, S. (2012).Survival and growth of Nauclea diderrichii and Pericopsis elata in monoculture and mixed species plots in Ghana. Journal of Tropical Forest Science; 24(1), 37-45

12. Dearborn, D.C., \& Kark, S. (2010). Motivations for conserving urban biodiversity. Conservation Biology, 24: 432440.

13. Whitlow, T.H., \& Bassuk N.L. (1987). Trees in difficult sites. Journal of Arboriculture, 13(1), 10-17.

14. Yang, J. (2009). Assessing the impact of climate change on urban trees species selection: A case study in Philadelphia. J. For. 107(7), 364-372.

15. Calaza, P., Cariñanos, P., Escobedo, F. J., Schwab, J., \& Tovar, G. (2018). Building green infrastructure and urban landscapes. Unasylva, 69(250), 11-21.

16. Kent, M., \& Coker, P. (1992). Vegetation Description and Analysis: A Practical Approach. Chichester, England: John Wiley \& Sons, pp 361.

17. Guo, Y., Gong, P., \& Amundson, R. (2003). Pedodiversity in the United States of America. Geoderma 117: 99-115.

18. Brashears, M.B., Fajvan M.A., \& Schuler, T. M. (2004). An assessment of canopy stratification and tree species diversity following clear cutting in central Appalachian hardwoods. Forest Science, 50:54-64.

19. Aidar, M.P.M., Godoy, J.R.L., Bergmann, J., \& Joly, C.A. (2001). Atlantic forest succession over calcareous soil, Parque Estadual Turísitico does Alto Ribeira PETAR, SP. Revista Brasileira de Botânica, 24:455-469.

20. L. E., Tyler, C. B., \& Schroeder, S. A.77-98. Seattle: USDA Forest Service, Pacific Northwest Research Station. 